\title{
Comparison of Hematological and Biochemical Profiles of Late Pregnant and Non-Pregnant Thoroughbred Mares
}

\author{
(PERBANDINGAN HEMATOLOGI DAN PROFIL BIOKIMIA DARAH KUDA RAS \\ THOROUGHBRED YANG SEDANG BUNTING TUA DAN YANG TIDAk BUNTING)
}

\author{
Murat Onur Yazlik, Ezgi Dikmeoglu, Arzu Esen, \\ Ufuk Kaya, Özgenur Kafkas, Burak Baran, Murat Göcen \\ Department of Obstetrics and Gynecology, \\ Faculty of Veterinary Medicine, \\ Ankara University,

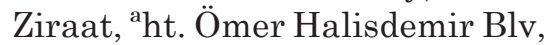 \\ 06110 Altýndad/Ankara, Turkey \\ Email: yazlik@ankara.edu.tr
}

\begin{abstract}
The maternal body must adapt to fetal growth and development during the state of pregnancy for successful foal and mother. Pregnancy status as in other mammals is related to physiology and hematology. This study aimed to compare the hematology profiles and biochemical parameters of late pregnant and non-pregnant mares. Twenty-two mares were included in the study. Mares were divided into two groups according to the pregnancy status. Hematology profile and biochemical parameters were analyzed from blood samples collected from the jugular vein. All data were analyzed using Stata 12/MP4. White blood cell count, lymphocyte, red blood cell count, hemoglobin concentration, hematocrit, monocyte and percentage of monocyte were significantly lower in non-pregnant mares compared to late pregnant mares $(\mathrm{P}<0.05)$. No significant differences were noted in values of neutrophil, eosinophil, mean cell volume, mean corpuscular hemoglobin concentration, mean corpuscular hemoglobin, platelet, mean platelet volume, red cell distribution width in both groups $(\mathrm{P}>0.05)$. On the other hand, biochemical parameters analysis showed that calcium, total bilirubin, and triglyceride concentrations were greater in late pregnant mares $(\mathrm{P}<0.05)$. However, urea, albumin, cholesterol, and magnesium concentrations were similar among groups $(\mathrm{P}>0.05)$. In conclusion, the present study showed hematology profile and biochemical parameters differences in late pregnant and non-pregnant mares. These values could be useful in clinical practices to assess the situation of late pregnant mares.
\end{abstract}

Keywords: pregnant mare; hematology; biochemical profile; thoroughbred

\begin{abstract}
Tubuh induk kuda harus beradaptasi dengan tumbuh kembang fetus selama kebuntingan supaya induk berhasil melahirkan dan anak kuda berhasil dilhirkan. Status kebuntingan seperti pada mammalia lainnya selalu berkaitan secara fisiologi dan hematologi. Penelitian ini bertujuan membandingkan gambaran parameter hematologi dan profil biokimia darah kuda bunting tua dengan yang tidak bunting. Sebanyak 22 ekor induk kuda dilibatkan dalam penelitian ini. Induk kuda tersebut dibagi menjadi dua kelompok menurut status kebuntingannya. Profil hematologi dan parameter biokimia, dianalisis berdasarkan sampel darah yang diambil pada vena jugularis. Seluruh data dianalisis menggunakan Stata 12/MP4. Jumlah sel darah putih, limfosit, jumlah sel darah merah, kadar hemoglobin, hematokrit, monosit dan persentase monosit, ditemukan nyata lebih rendah pada induk kuda yang tidak bunting dibandingkan dengan induk kuda yang sedang bunting tua $(\mathrm{P}<0,05)$. Perbedaan yang tidak nyata tercatat pada kedua kelompok kuda dalah hal nilai neutrofil, eosinofil, mean cell volume, mean corpuscular hemoglobin concentration, mean corpuscular hemoglobin, keping-keping darah/platelet, mean platelet volume, dan luasnya distribusi sel darah merah $(\mathrm{P}>0,05)$. Sementara itu, analisis terhadap parameter biokimia menunjukkan
\end{abstract}


bahwa kadar calcium, total bilirubin, dan trigliserida ditemukan lebih tinggi pada kuda bunting tua $(\mathrm{P}<0,05)$. Namun, urea, albumin, cholesterol, dan magnesium ditemukan kadarnya sama pada kedua kelompok kuda $(\mathrm{P}>0.05)$. Simpulan penelitian ini menunjukkan bahwa profil hematologi dan parameter biokimia darah kuda yang bunting tua berbeda dengan kuda induk yang tidak bunting. Nilai-nilai yang diperoleh dalam penelitian ini, dalam praktek klinik diharapkan bermanfaat dalam memberi penilaian kepada kuda bunting tua.

Keywords: kuda bunting; hematologi:, profil biokimia: thoroughbred

\section{INTRODUCTION}

The maternal body must adapt to fetal growth and development during the state of pregnancy for successful foal and mother (Hadden and McLaughlin, 2009). Both the blood and the body fluids differs in the course of gestation to response fetal and placental developmental demands, with important divergences in blood volume and its components (Carlin and Alfirevic, 2008). Hematology profile and biochemical parameters are important diagnostic tools in equine medicine. It is crucial to distinguish these physiological changes from pathological changes which may mare and fetus health under a risk and necessitate immediate medical intervention (Faramarzi et al., 2018). However, following the blood parameters might help monitor the health of pregnant mares. Despite all the homeostatic mechanisms to keep blood parameters within the physiologic ranges, physiological, biochemical changes in the blood are potential to occurs throughout the peripartum period (Harvey et al., 2005; Piccione et al., 2017). Especially, physiological changes occur in the last trimester of pregnancy. The lack of scientific papers referring to hematology profile and biochemical parameters comparisons in late pregnant and non-pregnant mares makes it difficult for the diagnosis of clinical veterinarians (Orozco et al., 2007). Different studies were performed about the pregnancy of mares for determining the changes in immunology, hemostasis, biochemistry, and hematology profiles (Bazzano et al., 2014, Bazzano et al., 2016). However, there are different factors that affect the hematology profile as age (mare or foal), breed, and reproductive status (Weiss and Wardrop, 2010).

In the present study, it was hypothesized that pregnancy status might have a role in hematology profile and biochemical parameters of similar age and breed mares. Also, body condition score might be used as a screening tool for pregnant mares. The present study aimed to examine the difference in hematology profile and some selected biochemical parameters in late pregnant and non-pregnant similar-aged Thoroughbred mares.

\section{RESEARCH METHODS}

\section{Animals}

This study was conducted in one geographic area. The ages of the horses were ranged between 10 to 20 and Thoroughbred was housed in individual straw-bedded boxes at the same center. Animals were fed twice daily and adlibitum access to water. Routine physical examinations, anthelmintic, and vaccinations were performed by the same veterinarian. A total of 13 non-pregnant and 9 late pregnant horses (8 to 10 months of pregnancy) were included in the present study. Animals are allocated into two groups according to their pregnancy status. The pregnancy examination was performed by transrectal examination and ultrasound (SIUI CTS 800, China). The day of pregnancy was calculated according to conception date. Body condition scores of mares were determined by using the Henneke scoring system (Frank, 2011).

\section{Blood Sampling and Analyses}

All blood samples were collected before morning feeding. Blood samples were collected from the jugular vein by using an 18-gauge needle and a $20 \mathrm{ml}$ syringe. Ten $\mathrm{ml}$ of each sample was transferred into the vacutainer tubes that contain $15 \%$ ethylenediaminetetraacetic acid (EDTA). The other $10 \mathrm{ml}$ of the sample was transferred to a plain vacutainer tube without any anticoagulant for serum analyses. All blood samples stored immediately in the icebox until transfer to the laboratory. Plain tubes were centrifuged for 10 minutes at $3000 \mathrm{rpm}$. Then serum samples were separated and transferred into $2 \mathrm{ml}$ tubes and frozen at 20 ! until analysis. 


\section{Complete Blood Count}

The tubes that contained EDTA were used for complete blood count analysis. The number of white blood cells (WBC), red blood cells (RBC), hemoglobin (HB), hematocrit (HCT), mean cell volume $(\mathrm{MCV})$, mean cell hemoglobin $(\mathrm{MCH})$, mean cell hemoglobin concentration (MCHC), mean platelet volume (MPV), red cell distribution width (RDW) and platelet (PLT) count were measured by using an automated hematology analyzer (Exigo Eos, Sweden).

\section{Biochemical Analysis}

Serum samples were analyzed to determine urea, albumin, cholesterol, bilirubin, triglyceride, calcium, and magnesium by using commercial kits following the manufacturer's instructions with an autoanalyzer (Erba XL 600, Germany) in Ankara University, Faculty of Veterinary Medicine Diagnostic Laboratory. All analyses were calibrated by using Erba XL Multical and calibration was verified using two control serums (Erba Norm and Erba Path, Germany).

\section{Statistical Analysis}

Before performing the statistical analysis, data were examined with Shapiro-Wilk test for normality and Levene test for homogeneity of variances as parametric test assumptions. Descriptive statistics for each variable were calculated. Independent Sample T test was used to evaluate the differences between groups for the variables when parametric test assumptions were provided and Mann-Whitney U test was used if the assumptions were not provided. $\mathrm{P}<0.05$ was considered significant in all analyses. All data were analyzed using Stata 12/MP4 program.

\section{RESULTS AND DISCUSSION}

The mean age and body condition scores were similar for both groups. The results for blood samples were presented as mean - standard deviation (SD).

\section{Hematology Profile}

The hematological profiles were summarized in Table 1. The mean value of WBC count was higher in late pregnant in compare to nonpregnant mares. Lymphocytes $(\mathrm{P}<0.001)$ and monocytes $(\mathrm{P}=0.008)$ were higher in late pregnant in compare to non-pregnant mares. On the other hand, the percentage of monocytes was greater $(\mathrm{P}=0.029)$ but, lymphocyte percentage was similar in late pregnant and non-pregnant mares respectively. RBC, HGB, and HCT of hematology profile were greater in late pregnant mares.

\section{Serum Biochemical Profile}

The biochemical profile is presented in Table 2 and 3 . The mean values of urea, albumin, cholesterol, magnesium was similar for both groups of animals $(\mathrm{P}>0.05)$. On the other hand, calcium $(\mathrm{P}=0.032)$, bilirubin $(\mathrm{P}=0.008)$, and triglyceride $(\mathrm{P}=0.045)$ concentrations were higher in late pregnant mares.

This study shows the differences in hematology profile and biochemical parameters of late pregnant and non-pregnant mares. Mares during the peripartum period are susceptible to have a series of changes in blood hematology and serum biochemistry, because of the hormonal dynamics in this period. Metabolic changes in the course of gestation are complicated situations such as, outcome of fetal development, changes in the body structure of the dam (Barbosa et al., 2018).

In accordance with other studies, $\mathrm{RBC}$ count was in physiological ranges at the later stages of pregnancy (Harvey et al., 1994). However, the present study showed that the RBC count was higher in late pregnant mares. Possibly increased fetal oxygen requirements might be responsible for this condition (Satué, 2004). Fetal growth increases in that period of pregnancy thus the demand for oxygen increases. The increased oxygen demand compensated by the endocrine system which releases erythropoietin by renal tissues. This glycoprotein stimulates the production of erythrocytes from the bone marrow (Lurie, 1993). The results are similar to those of Satué et al., (2008). In present study HCT was greater in late pregnant mares. The possible explanation in this difference might be that in late pregnancy blood volume increase represent important adjustments to keep up with the increased blood flow to the organs such as uterus and kidneys. In present study, HCT was greater in late pregnant mares. The possible explanation in this difference might be that in late pregnancy blood volume increase indicates important adjustments to keep up with the increased blood flow to the organs such as uterus and kidneys (Bazzano et al., 216). Orozco et al. (2007) reported a physiologically higher level of RBC, HCT and HGB levels can be associated with a better 
Table 1. Complete blood count (Mean $\pm \mathrm{SD})$ in late pregnant and non-pregnant mares and the reference ranges (AHDC, 2020).

\begin{tabular}{lllll}
\hline Parameter & Pregnant & Non-Pregnant & P value & Reference \\
\hline WBC(x10 $)$ & $10.68 \pm 1.79$ & $6.18 \pm 1.56$ & 0.03 & $5.2-10.1 \times 10^{3} / \mu \mathrm{l}$ \\
LYM(x10 $)$ & $3.62 \pm 0.79$ & $1.64 \pm 0.48$ & 0.001 & $1.2-4.9 \times 10^{3} / \mu \mathrm{l}$ \\
NEUT(x10 & $5.64 \pm 1.69$ & $3.94 \pm 1.40$ & 0.122 & $2.7-6.6 \times 10^{3} / \mu \mathrm{l}$ \\
LYM \% & $35.34 \pm 9.55$ & $28.34 \pm 9.12$ & 0.270 & $\% 18-55$ \\
MON \% & $11.80 \pm 2.80$ & $7.78 \pm 1.9$ & $\mathbf{0 . 0 2 9}$ & $\% 0-7$ \\
EOS \% & $0.82 \pm 1.13$ & $1.42 \pm 1.76$ & 0.539 & $\% 0-16$ \\
RBC Count $\left(\mathrm{x} 10^{6}\right)$ & $9.66 \pm 0.58$ & $7.61 \pm 1.89$ & 0.050 & $6.6-9.7 \times 10^{6} / \mu \mathrm{l}$ \\
HGB $(\mathrm{g} / \mathrm{dl})$ & $18.34 \pm 1.3$ & $13.92 \pm 3.61$ & 0.033 & $11.8-15.9 \mathrm{~g} / \mathrm{dl}$ \\
HCT(\%) & $46.82 \pm 1.65$ & $31.98 \pm 9.29$ & 0.046 & $\% 34-46$ \\
MCV(fl) & $45.46 \pm 1.88$ & $44.44 \pm 3.44$ & 0.577 & $43-55 \mathrm{fl}$ \\
MCHC(g/dl) & $41.78 \pm 1.62$ & $41.24 \pm 1.25$ & 0.572 & $34-37 \mathrm{~g} / \mathrm{dl}$ \\
RDW(fl) & $27.50 \pm 1.44$ & $26.56 \pm 2.80$ & 0.523 & $15-21 \mathrm{fl}$ \\
RDW \% & $17.38 \pm 0.31$ & $17.28 \pm 0.79$ & 0.801 & $\% 16.3-19.3$ \\
\hline
\end{tabular}

Table 2. Serum biochemical profile $((\mathrm{Mean} \pm \mathrm{SD})$ in late pregnant and non-pregnant mares and reference ranges (Yarsan, 2019).

\begin{tabular}{lccrr}
\hline Parameter & Pregnant & Non-Pregnant & P value & Reference \\
\hline Urea $(\mathrm{mg} / \mathrm{dL})$ & $35.68 \pm 3.94$ & $34.86 \pm 6.26$ & 0.810 & $8-27 \mathrm{mg} / \mathrm{dL}$ \\
Albumin $(\mathrm{g} / \mathrm{dL})$ & $3.13 \pm 0.22$ & $2.91 \pm 0.34$ & 0.258 & $2.5-3.7 \mathrm{~g} / \mathrm{dL}$ \\
Cholesterol $(\mathrm{mg} / \mathrm{dL})$ & $139.00 \pm 36.27$ & $125.40 \pm 32.21$ & 0.548 & $75-150 \mathrm{mg} / \mathrm{dL}$ \\
Calcium $(\mathrm{mg} / \mathrm{dL})$ & $13.32 \pm 0.23$ & $12.60 \pm 0.58$ & 0.032 & $11.2-13.6 \mathrm{mg} / \mathrm{dL}$ \\
\hline
\end{tabular}

${ }^{*} \mathrm{P}<0.05$ considered as statistically significant (pregnant versus non-pregnant group)

Table 3. Serum biochemical profile ((Mean $\pm \mathrm{SD})$ in late pregnant and non-pregnant mares and reference ranges (Yarsan, 2019).

\begin{tabular}{|c|c|c|c|c|}
\hline Parameter & Pregnant & Non-Pregnant & $\mathrm{P}$ & Reference \\
\hline Bilirubin (mg/dL) & $3.17 \pm 2.80$ & $0.84 \pm 0.48$ & 0.008 & $1.0-2.0 \mathrm{mg} / \mathrm{dL}$ \\
\hline Triglyceride(mg/dL) & $33.40 \pm 11.07$ & $17.29 \pm 7.16$ & 0.045 & $<50 \mathrm{mg} / \mathrm{dL}$ \\
\hline Magnesium (mg/dL) & $2.47 \pm 0.34$ & $2.03 \pm 0.43$ & 0.151 & $2.2-2.8 \mathrm{mg} / \mathrm{dL}$ \\
\hline
\end{tabular}

physiological condition (Vaz et al., 2000). In Thoroughbred horses, such differences can be noted compare to others. And explanation in these differences was the maximum metabolic nutrient utilization due to sports activities (Orozco et al., 2007). This explanation coincides with the previous explanation (Satué, 2004). Iron deficiency anemia is reported in mares and Satué et al. (2012) reported mild anemia at the end of pregnancy. Iron supplementation increased HGB values in anemia cases also observed in pregnant women (Casanueva et al., 2006). Therefore, in the current study, the concentration of HGB in late pregnant mares was greater compared to non-pregnant mares, it is thought that possible pregnancy anemia is not observed during the study process and there is no iron deficiency in these mares.

In present study MCV, MCHC, platelet, $\mathrm{MCH}$ and MPV did not significantly change and this is in agreement with previous studies on mares, which reported no significant changes in MCV, MCHC, and PLT (Harvey et al., 1994, Bazzano et al., 2014, Faramazi et al., 2018). 
As pregnancy progresses, endogenous adrenaline release increases, resulting in higher cell mobilization and increased blood leukocyte concentration (Orozco et al., 2007). In this study, leukocyte concentration increased in late pregnant mares. Parallelly, in humans, adrenocorticoid-related leukocytosis is also observed during pregnancy (Bazzano et al., 2014). The lymphocyte count in present study differs from the others because the lymphocyte count is thought to decrease because of the cortisol, whose foaling time approaches (Nagel et al., 2012) not only endogen but also exogenous glucocorticoid treatment resulted with lymphopenia (Harvey et al., 1994). In the current study, possible cortisol release may not have occurred since the delivery time was longer. Monocyte counts were greater in late pregnant mares in compare to non-pregnant mares. An increase in the number of monocyte count may indicate stress. Miglio et al. (2019) explained that stress due to sampling activity produces mobilization of the marginal pool of immune cells. Possibly increased count of monocytes might be conditional on this mechanism.

To analyze the physiological changes to pregnancy in mares, biochemical parameters have been represented to be a substantial tool. It is essential to understand the physiological changes in biochemical parameters to specify diagnosis, prognosis, and evolution of disease; physiological adaptations to pregnancy (Aoki and Ishii, 2012; Barbosa et al., 2018). Total bilirubin concentration was greater in late pregnant mares. In late pregnant horses HGB level were greater in compared to non-pregnant horses and this might be resulted with increased bilirubin concentration. Because the bilirubin is released from hemoglobin and excreted in bile. On the other hand, the reason of the increase in total bilirubin might be by the reason of secondary cholestasis due to enlarged uterus in late pregnancy (Mariella et al., 2014). The concentration of cholesterol similar in both groups and these animals were housed together under the same condition. Blood cholesterol concentration influenced by some factors such as the ingested food, the absorbed food from the intestine, the amount of synthesized in the liver, the usage of the body, the reabsorbed amount, and the amount excreted by feces (Aoki and Ishii, 2012). Also, these horses had similar body condition score. The parameter that demonstrates a vigorously significant difference between late pregnant and non-pregnant mares was serum triglyceride levels (Vincze et al., 2015). Similar results were shown in the present study.

The concentration of triglyceride was greater in late pregnant mares. Serum triglyceride are reported to increase fractionally throughout gestation in women (Harvey et al., 2005) and peak concentrations take place near term in rats (LaBorde et al., 1999). As Watson et al. (Watson et al., 1993) reported, the reason of the escalated plasma triglyceride values was referred to escalated hepatic triglyceride synthesis and VLDL secretion, because plasma activities of lipoprotein lipase and hepatic lipase (the enzymes responsible for catabolism of VLDL) were not changed by pregnancy.

The albumin concentration was not different in both groups. Albumin is a negative acutephase protein and influenced the dehydration status of the animal. The increase of albumin concentrations signed to dehydration in mares. The albumin concentration is in harmony with the body condition score. This means that the animals included in the study had no dehydration problem.

The elevated demand for minerals along with the peripartum period determines noteworthy alterations in mineral metabolism. Calcium is an important ion that has a role in immunity and cell biology and muscle tissue. In the course of the peripartum period, the mare has to overcome extraordinary mineral necessities for developing fetus as so the growing foal, particularly in the matter of $\mathrm{Ca}$ and $\mathrm{P}$. The substantial changes in peripartum mare's macro mineral profile enables to have enhanced information about mineral intercommunions and their alterations during specific physiological conditions such as late pregnancy (Bazzano et al., 2016). Others were focused on the usage of calcium at foaling and its relationship with uterine contractions and postpartum evaluation of parturition status (Mariella et al., 2014). Most of horse owner giving extra calcium and different type of feed for pregnant mare which contain higher level of calcium. Alfalfa is also a source of calcium and iron. The present study showed that calcium concentration in late pregnant mares was greater than non-pregnant mares. Placental transfer of $\mathrm{Ca}$ was documented in mares (Wooding et al., 2000). Also, in the later stages of pregnancy fetal $\mathrm{Ca}$ demand increases for skeletal development and mineralization. In consequence of homeostasis in metabolism to meet increasing demands, the serum 
concentration of $\mathrm{Ca}$ might be increased in late pregnant mares.

\section{CONCLUSION}

In conclusion, the present study revealed hematological and biochemical differences in late pregnant and non-pregnant mares. These values could be useful in clinical practices to assess the situation of late pregnant mares.

\section{SUGGESTION}

Further studies should be conducted to understand the mechanism which affecting the hematology profile and biochemical parameters during late pregnancy.

\section{Animal Rights Statement: \\ None required.}

\section{Conflict of Interest Statement}

The authors declared that they have no potential conflict of interest with respect to the authorship and/or publication of this article.

\section{REFERENCES}

AHDC (Animal Health Diagnostic Center). 2020. Cornell University, Collage of Veterinary Medicine. https://www.vet.cornell.edu/ animal-health-diagnostic-center/ laboratories/clinical-pathology/referenceintervals/hematology [19 August 2020].

Aoki T, Ishii M. 2012. Hematological and biochemical profiles in peripartum mares and neonatal foals (heavy draft horse). Equine Vet J 32: 170-176.

Barbosa FC, Silva MV, Costa PC, Souza RR, Guimaraes EC, Mundim AV. 2018. Physiological variations of serum biochemical profile in quarter horse mares at peripartum and in their neonatal foals. $J$ Biosci 34: 970-997.

Bazzano M, Giannetto C, Fazio F, Rizzo M, Giudice E, Piccione G. 2014. Physiological adjustments of haematological profile during the last trimester of pregnancy and the early post partum period in mares. Anim Reprod Sci 149: 199-203.
Bazzano M, Giudice E, Giannetto C, Fazio F, Scollo C, Piccione G. 2016. The peripartum period influenced the serum macromineral profile in mares. Archives Animal Breeding 59: $65-70$.

Carlin A, Alfirevic Z. 2008. Physiological changes of pregnancy and monitoring. Best Pract Res Clin Obstet Gynaecol 22: 801-823.

Casanueva E, Viteri FE, Mares-Galindo M, Meza-Camacho C, Loría A, Schnaas L, Valdés-Ramos R. 2006. Weekly iron as a safe alternative to daily supplementation for nonanemic pregnant women. Arch Med Res 37: 674-682.

Faramarzi B, Rich LJ, Wu J. 2018. Hematological and serum biochemical profile values in pregnant and non-pregnant mares. Can J Vet Res 82: 287-293.

Frank N. 2011. Equine metabolic syndrome. Veterinary Clinics: Equine Practice 27(1): 73-92.

Hadden DR, McLaughlin C. 2009. Normal and abnormal maternal metabolism during pregnancy. Semin Fetal Neonatal Med 14: 66-71.

Harvey JW, Asquith RL, Patel MG, Kivipelto J, Chen CL, Ott EA. 1994. Haematological findings in pregnant, postparturient and nursing mares. Comparative Haematology International 4: 25-29.

Harvey JW, Pate MG, Kivipelto J, Asquith RL. 2005. Clinical biochemistry of pregnant and nursing mares. Vet Clin Pathol 34: 248254.

LaBorde JB, Wall KS, Bolon B, Kumpe TS, Patton R, Zheng Q, Kodell R, Young JF. 1999. Haematology and serum chemistry parameters of the pregnant rat. Lab Anim 33: $275-287$.

Lurie S. 1993. Changes in age distribution of erythrocytes during pregnancy: a longitudinal study. Gynecol Obstet Invest 36: $141-144$.

Mariella J, Pirrone A, Gentilini F, Castagnetti C. 2014. Hematologic and biochemical profiles in Standardbred mares during peripartum. Theriogenology 81: 526-534.

Miglio A, Morelli C, Maresca C, Felici A, Di Giambattista A, Antognoni MT. 2019. Hematologic reference intervals for the 
Italian Heavy Draft horse. Comp Clin Path 28: 833-840.

Nagel C, Erber R, Bergmaier C, Wulf M, Aurich J, Möstl E, Aurich C. 2012. Cortisol and progestin release, heart rate and heart rate variability in the pregnant and postpartum mare, fetus and newborn foal. Theriogenology 78: 759-767.

Orozco CAG, Martins CB, D'Angelis FHDF, Oliveira JVD, Lacerda-Neto JCD. 2007. Hematological values and total protein of Brasileiro de Hipismo and Breton mares during pregnancy. Ciência Rural 37: 16951700.

Piccione G, Arfuso F, Abbate F, Giannetto C, Panzera M, Rizzo M, Fazio F. 2017. Adrenocorticotrophic hormone and cortisol levels during late pregnancy and post-foaling period in mares. Animal Science Papers and Reports 35: 173-180.

Satué K. 2004. Hematologíaen la yegua Pura Raza Española de Estirpe Cartujana. PhD Thesis, Moncada, Valencia, Spain. CEUCardenal Herrera University.

Satué K, Domingo R. 2008. Microhematocrit values, total proteins and electrolytes concentrations in Spanish Purebred mares during pregnancy. In: Proceedings of 10th Annual Congress of the European Society of Veterinary Clinical Pathology (ESVCP) and the 8th Biennial Congress of the International Society for Animal Clinical Pathology (ISACP), European Society of
Veterinary Clinical Pathology, Barcelona, Spain.

Satué K, Hernández A, Muñoz A. 2012. Physiological factors in the interpretation of equine hematological profile. HematologyScience and Practice 24: 573-596.

Vaz BBD, Lacerda Neto JC, Santana AE, Summa RP, Penteado C. 2000. Constituintes hematimétricos do sangue de éguasgestantes de raça Árabe. Veterinária Noticias 6: 51-55.

Vincze B, Kutasi O, Baska F, Szenci O. 2015. Pregnancy-associated changes of serum biochemical values in Lipizzaner Broodmares. Acta Vet Hung 63: 303-316.

Watson TDG, Burns L, Packard CJ, Shepherd J. 1993. Effects of pregnancy and lactation on plasma lipid and lipoprotein concentrations, lipoprotein composition and post-heparin lipase activities in Shetland pony mares. J Reprod Infertil 97: 563-568.

Weiss DJ, Wardrop KJ, Douglas J. 2010. Schalm's Veterinary Hematology, $6^{\text {th }}$ Ed., Ames, Iowa USA. Blackwell Publishing Ltd. Pp. 821-828.

Wooding FBP, Morgan G, Fowden AL, Allen WR. 2000. Separate sites and mechanisms for placental transport of calcium, iron and glucose in the equine placenta. Placenta 21 : 635-645.

Yarsan E. 2019. At Hekimliði Ankara, Türkiye, Günep Týp Kitapevleri. Pp. 155-157. 